\title{
Is corporate social responsibility a new spirit of capitalism?" ${ }^{1}$
}

\author{
Bahar Ali Kazmi \\ Aston Business School \\ Aston University Aston triangle \\ Birmingham \\ B4 7ET \\ UK \\ Tel: +44(0) 1215371 \\ b.kazmi@aston.ac.uk \\ Bernard Leca \\ ESSEC Business School \\ Avenue Bernard Hirsch \\ 95021 Cergy-Pontoise Cedex \\ FRANCE \\ Fax : + 33(0)134439277 \\ Tel: + 33(0)134433001 \\ Email : leca@essec.edu \\ Philippe Naccache \\ Toulouse Business School \\ 20 Boulevard Lascrosses, \\ 31068 Toulouse \\ France \\ Tel. (0033)247717171 \\ Fax (0033)247717210 \\ p.naccache@tbs-education.fr
}

\footnotetext{
${ }^{1}$ We would like to thank the editor and the anonymous reviewers for their suggestions and constructive comments which helped us greatly to improve the manuscript. We would also like to thank Annick Bourguignon, Jean Pascal Gond, Dirk Matten, Emmanuelle Michotte, André Spicer and Darren McCabe for the exchanges we had on this topic and Atif Khan for his research assistance. All mistakes remain ours.
} 


\title{
Is corporate social responsibility a new spirit of capitalism?
}

\begin{abstract}
Our study casts doubt on whether the managerial literature on corporate social responsibility is currently capable of developing a persuasive discourse to bring about change in corporate capitalism. By applying the framework and methodology of the spirit of capitalism, introduced by Boltanski and Chiapello (2005), to a corpus of managerial books, we suggest that corporate social responsibility exhibits the core characteristics that together exemplify the 'spirit of capitalism'. However, corporate social responsibility deals inadequately with the two key characteristics of the spirit of capitalism - security and fairness - by disregarding individual security and tangible rewards for workers who play decisive roles in enacting the spirit. The lack of consideration for workers could weaken the potential of corporate social responsibility to grow into a new spirit of capitalism and to bring about changes envisioned by critical management studies in corporate capitalism.
\end{abstract}

\section{Keywords}

Corporate social responsibility, spirit of capitalism, security, fairness, critical performativity 


\section{Is corporate social responsibility a new spirit of capitalism?}

\section{Introduction}

Critical scholars have been ambivalent about corporate social responsibility (CSR). Some argue that it is merely a smokescreen, concealing the exploitative nature of corporate capitalism (Banerjee, 2007). In this view, as Fleming et al. (2013: 338) summarize it, 'none of it [CSR] really mattered when it comes to the day-to-day [corporate] behaviour'. Others see a potential in CSR to be a source of change in corporate capitalism, and possibly contribute to performativity - i.e. the ongoing process of acting and enacting the critical management studies (CMS) project of encouraging the development of management that challenges the social injustice and environmental destructiveness of current corporate capitalism (Adler et al., 2007; Spicer et al., 2009). This may happen, as Christensen et al. (2013) argue, because CSR is not an accurate account of reality but an 'aspirational talk' that shows the ambition of companies to become socially responsible. Such aspirational talk can achieve performativity because it creates corporate commitment as well as public expectations, which can be turned into important resources for making companies meet their own social and ethical claims. This performative potential of CSR might favour the form of management envisioned by CMS through micro change and the 'reflexive conscientization' of managers (Wickert and Schaefer, 2014).

In this paper, we seek to contribute to this performativity debate in CMS on the potential of CSR as a source of change in corporate capitalism and its likely contribution to realizing the CMS project. To do so, we draw on work by Boltanski and Chiapello (2005) on the 'spirit of capitalism'. Drawing from Weber ([1930] 1992), Boltanski and Chiapello use the notion of 'spirit of capitalism' to describe and explain successive spirits developed to address the dominant critiques of capitalism at the time in order to secure the commitment of 
protagonists, capitalists and wage-earners, to capitalism. Starting at the end of the $19^{\text {th }}$ century until the time of their writing (the 1990s), Boltanski and Chiapello distinguish three successive spirits of capitalism that came to dominate. They label the one that was dominant at the time of their writing the 'project-based' spirit; this justified capitalism as the best way for anyone to express individual creativity and talent. In this way, it was seen to ensure personal success through navigating between multiple projects and networks. According to Boltanski and Chiapello (2005), the 'spirit of capitalism' not only provides justification for but also changes capitalism. This aspect of Boltanski and Chiapello's work has generated significant interest within the CMS community, as it offers new insights into the role of critiques of capitalism (e.g. Christiansen, 2010; Cremin, 2010; du Gay and Morgan, 2013; Parker, 2008). In this study, we ask whether CSR might become a new spirit of capitalism, providing a new justification to the protagonists, and might change capitalism in a direction consistent with the CMS project. To do so, we explore: first, whether CSR exhibits the core elements of a new spirit of capitalism, as defined by Boltanski and Chiapello (2005); and, second, whether CSR is likely to change corporate capitalism in the direction envisioned by CMS. We draw inspiration from Boltanski and Chiapello (2005) for the theory and the method and, in so doing, analyse a corpus of managerial texts, consisting of 22 books on CSR (see Appendix 1).

Our analysis offers three contributions. First, CSR (as presented in the books in our corpus) exhibits the core characteristics of the spirit of capitalism - excitement, security and fairness - and addresses a major current critique of corporate capitalism: its sustainability (which previous spirits of capitalism did not address). However, the books pay inadequate attention to the needs and interests of workers, devoting more attention to the demands of managers. We suggest that this can be seen as a weakness, since Boltanski and Chiapello (2005) suggest that disregarding principal protagonists (workers) undermines the potential of a discourse to 
change capitalism. Second, our analysis contributes to research on the changes in the spirit of capitalism. It suggests that while all the previous spirits of capitalism promised individual freedom to potential protagonists, the books that we have analysed make a different promise. They emphasize one's duties to the collective, suggesting that CSR is a way to perform those duties, and to enjoy social and moral benefits from doing so. Finally, we discuss the potential of CSR to change corporate capitalism in the direction envisioned by CMS, and suggest that it is unlikely to contribute to the realization of the CMS project because it ignores the legitimate (i.e. security- and fairness-related) needs and interests of workers. In conclusion, we discuss the areas of research that can be further developed by using the framework of the spirit of capitalism.

We present this argument in the following manner. First, we discuss Boltanski and Chiapello's (2005) framework for analysing and understanding the 'spirit of capitalism'. Second, we present our research methodology. Third, we discuss our findings, draw conclusions and suggest avenues for further research.

\section{Boltanski and Chiapello's framework for analysing the transformation in the spirit of capitalism}

Referring to Weber ([1930] 1992), Boltanski and Chiapello (2005: 2) define 'the spirit of capitalism' as 'the ideology that justifies engagement in capitalism'. Boltanski and Chiapello preferred the notion of spirit of capitalism to that of ideology, which (they argue) has several definitions.They insist that the spirit of capitalism is an ideology in the sense proposed by Louis Dumont, as representing 'a set of shared beliefs, inscribed in institutions, bound up with actions, and hence anchored in reality' (Boltanski and Chiapello, 2005: 3). However, it is distinct from the Marxist definition of ideology, which directs attention towards the contradiction between a 'moralizing discourse' of capitalism and its practices (Boltanski and Chiapello, 2005: 3; Chiapello, 2003: 163). In short, the spirit of capitalism consists of a set of 
beliefs that justifies capitalism in order to gain and maintain the commitment of its protagonists and to respond to the critiques of its opponents.

The protagonists of capitalism consist of two groups: the capitalists and the wage-earners. The capitalists are the shareholders who invest their capital in firms to make profit. The wage-earners invest their labour and in so doing 'surrender all property rights over the fruit of their efforts [to the firm]' (Boltanski and Chiapello, 2005: 7) as well as entering into voluntary subjection. Boltanski and Chiapello argue, along with other authors such as Critchley (2007), that there is a deficit of motivation at the heart of capitalism, and that this needs to be addressed. Both protagonists of capitalism - capitalists and wage-earners - are likely to get demotivated, because the former, burdened with risks and uncertainties, become chained to the insatiable process of accumulating capital, while the latter must consent to losing ownership of the products of their labour and must be willing to spend their working life in subordination. Overall, only a few such protagonists have any real chance of extracting a substantial benefit from capitalist practices (Boltanski and Chiapello, 2002; Chiapello, 2003; du Gay and Morgan, 2013), and capitalism is likely to suffer motivational deficit (Critchley, 2007). As Boltanski and Chiapello (2005: 7-8) put it:

\footnotetext{
albeit to an unequal extent depending upon the direction in which profit is sought, capitalist accumulation demands the mobilization of a very large number of people whose prospects of profit are very low, and each of whom is assigned only minute responsibility - or, at any rate, responsibility that is difficult to assess - in the overall accumulation process. Consequently, when they are not downright hostile to capitalist practices they are not particularly motivated to engage in them.
}

Boltanski and Chiapello (2005) further argue that providing justification to the protagonists, however, is not enough: capitalism must also respond to its critiques (see Table 1 for critiques from the $19^{\text {th }}$ and $20^{\text {th }}$ centuries). Unaddressed critiques can weaken capitalism, leading to doubt that can demotivate protagonists as they begin to agree with the critiques. For that 
reason, capitalism can be seen as a legitimate and worthwhile way to organize society only after producing justifications that address the critiques developed by its opponents. Like other authors (e.g. Debord, 1977; Jameson, 1991), Boltanski and Chiapello argue that the survival and growth of capitalism are linked to its capacity to integrate the critiques it faces. While other authors had already considered this dynamic (e.g. Hirschman, 1977; Pocock, 1972, 1985), Boltanski and Chiapello offer a distinctive approach. Instead of focusing on the connection between capitalism and the political conception of common good as these previous authors, Boltanski and Chiapello focus on the justifications aiming to secure the commitment of the protagonists. In so doing, they describe and explain how the critiques of capitalism become integrated, how they contribute to the transformation of the spirit of capitalism, and how the new spirit shapes corporate practices.

Boltanski and Chiapello (2005) describe a three-step process. First, critiques emerge that target the established spirit of capitalism on grounds where it fails to provide convincing justifications. This threatens the capacity of the established spirit to maintain the motivation of the protagonists, and potentially produces ungovernability (Chiapello, 2013) because it becomes challenging to manage companies. This crisis of governability demands changes. Second, supporters of capitalism select some of the critiques that they consider to be legitimate and to have the potential to reform capitalism without radically questioning it. Those critiques are acknowledged and integrated into a new spirit of capitalism. This new spirit emerges to explain how a reformed capitalism can deal with the critiques. Third, to do so convincingly, the new spirit of capitalism shapes corporate practices to make them consistent with the new spirit. In this sense, the spirit of capitalism is not merely rhetorical but also performative. The managerial texts that articulate the spirit of capitalism introduce new legitimate and acceptable ways of maximizing profit and accumulating capital, and make recommendations regarding managerial activities and the ways of organizing companies. . 
The three-step process detailed above is an heuristic tool to account for tendencies rather than a description of a linear course . Boltanski and Chiapello (2005) argue that the spirit of capitalism shapes views about how management should be perceived and performed; they stress that in order to secure the involvement of the protagonists (i.e. the capitalists and the wage-earners), the spirit of capitalism should be able to satisfy the following three criteria $^{2}$ :

1. Excitement. This means convincing people of how working within a capitalist system would animate and enliven them.

2. Security. This involves showing people how capitalism would protect them and their families.

3. Fairness. This involves demonstrating how capitalism contributes to the public interest and common good. It also means showing people that fairness includes a way to distinguish individuals whose actions should be valued and rewarded because they are considered 'good', i.e. in compliance with the spirit of capitalism.

By using this approach, Boltanski and Chiapello (2005) distinguish three successive spirits of capitalism, starting at the end of the $19^{\text {th }}$ century (see Table 1 ).

Table 1. The three previous spirits of capitalism.

\begin{tabular}{|c|c|c|c|}
\hline & $\begin{array}{l}\text { First spirit } \\
\text { End of } 19^{\text {th }} \text { century } \\
\text { to } 1930 \mathrm{~s}\end{array}$ & $\begin{array}{l}\text { Second spirit } \\
1940 \text { to } 1970 \text { s }\end{array}$ & $\begin{array}{l}\text { Third spirit } \\
\text { Since } 1980 \\
\text { (project-based) }\end{array}$ \\
\hline Critiques & $\begin{array}{l}\text { Conservative critique } \\
\text { Poverty and } \\
\text { insecurity } \\
\text { Destruction of } \\
\text { traditional rural } \\
\text { communities }\end{array}$ & $\begin{array}{l}\text { Social critique } \\
\text { Inequalities and } \\
\text { exploitation, } \\
\text { benefiting only the } \\
\text { capitalists } \\
\text { Class domination }\end{array}$ & $\begin{array}{l}\text { Artistic critique } \\
\text { Uniformity of } \\
\text { bureaucratic } \\
\text { structures } \\
\text { Boringness } \\
\text { Alienation }\end{array}$ \\
\hline
\end{tabular}

\footnotetext{
${ }^{2}$ The criteria of excitement/ security/ fairness are based on the analysis of the previous spirits of capitalism analysed by Boltanski and Chiapello and therefore new criteria of evaluating capitalism might emerge as promoters continue to develop new potential spirits of capitalism.
} 


\begin{tabular}{|c|c|c|c|}
\hline $\begin{array}{l}\text { Integration of those } \\
\text { critiques }\end{array}$ & $\begin{array}{l}\text { 'Bourgeois values' } \\
\text { Frugality and savings } \\
\text { as a way to become } \\
\text { bourgeois } \\
\text { Charity and } \\
\text { paternalism }\end{array}$ & $\begin{array}{l}\text { 'Fordist } \\
\text { compromise': good } \\
\text { salaries, lifelong } \\
\text { jobs, social dialogue, } \\
\text { managerial } \\
\text { capitalism }\end{array}$ & $\begin{array}{l}\text { Project-based } \\
\text { corporations } \\
\text { Network-based } \\
\text { corporations } \\
\text { More freedom and } \\
\text { opportunities; wage- } \\
\text { earners are their own } \\
\text { bosses }\end{array}$ \\
\hline Excitement & $\begin{array}{l}\text { Freedom from local } \\
\text { communities } \\
\text { Progress }\end{array}$ & $\begin{array}{l}\text { Career opportunities } \\
\text { Power positions }\end{array}$ & $\begin{array}{l}\text { No more } \\
\text { authoritarian } \\
\text { chiefs } \\
\text { Fuzzy organizations } \\
\text { Innovation and } \\
\text { creativity } \\
\text { Permanent change }\end{array}$ \\
\hline Security & $\begin{array}{l}\text { Personal property } \\
\text { Personal } \\
\text { relationships } \\
\text { Charity } \\
\text { Paternalism }\end{array}$ & $\begin{array}{l}\text { Long-term planning } \\
\text { Careers } \\
\text { Welfare state }\end{array}$ & $\begin{array}{l}\text { For the mobile and } \\
\text { the adaptable } \\
\text { Companies will } \\
\text { provide self-help } \\
\text { resources } \\
\text { Managing oneself }\end{array}$ \\
\hline Fairness & $\begin{array}{l}\text { A mix of domestic } \\
\text { and market fairness }\end{array}$ & $\begin{array}{l}\text { Meritocracy, valuing } \\
\text { effectiveness } \\
\text { Management by } \\
\text { objectives }\end{array}$ & $\begin{array}{l}\text { New form of } \\
\text { meritocracy, valuing } \\
\text { mobility and ability } \\
\text { to expand a network } \\
\text { Each project is an } \\
\text { opportunity to } \\
\text { develop } \\
\text { one's employability }\end{array}$ \\
\hline
\end{tabular}

Sources: Berland and Chiapello, 2009; Boltanski and Chiapello, 2002; Boltanski and Chiapello, 2005; Chiapello, 2009

The last spirit of capitalism identified by Boltanski and Chiapello (2005) is that developed to address the artistic critique, which had originated in the $19^{\text {th }}$ century. This critique challenged capitalism on the grounds that it lacked a sense of beauty and greatness, due to the growth of standardization and marketization. While the artistic critique had existed since the $19^{\text {th }}$ century, it had remained marginal. Yet, as students and young intellectuals schooled in what we might call the ethos of 1968 became increasingly receptive to it, this critique became diffused, denouncing Fordist capitalism as boring, based on the development of large firms 
that were overly bureaucratic and slow to respond to the demands of wage-earners (Boltanski and Chiapello, 2005: 38). According to Boltanski and Chiapello, the integration of the artistic critique took place in the 1990 s, as managerial books mentioned this critique and suggested ways to address it. This new spirit emphasized the importance of small units, networks and projects rather than large bureaucratic companies, insisting on the importance of speed of response. To ensure the commitment of the protagonists, this spirit also offered renewed sources of excitement, security and fairness. It was presented as a more exciting configuration of business, because it could set wage-earners free from bureaucracy and facilitate permanent change. Companies were advised to provide security to wage-earners through self-help resources, to maintain their 'employability' and flexibility. Finally, fairness was embedded in the way wage-earners were assessed, based on their capacity to fulfil projects, and their adaptability and mobility.

The emergence and transformation of the spirit of capitalism is not a linear process. Critiques of capitalism often exist long before they get acknowledged by the supporters of capitalism. The development of critiques and the emergence of a new spirit are likely to overlap. It can, therefore, be challenging to separate historical periods. For example, while this spirit of capitalism has been able to integrate the artistic critique, it has failed to integrate the sustainability critique that also emerged in the 1960s (Carson, 1962; Meadows et al., 1972) and became prominent later (Chiapello, 2013). While very much present in the 1970s, it did not become prominent enough to reorient capitalism until recently. The sustainability critique questions the ability of capitalism to assure the continuity of the human species and the sustainability of development. It highlights the impacts of capitalism and corporate activities on natural and social environments (e.g. Bakan, 2005; Banerjee, 2007; Klein, 2000; Stiglitz, 2006), eventually questioning whether capitalism can safeguard either the continuity of humans as a species or the sustainability of development (Purser et al., 1995). The 
sustainability critique cannot be addressed by the project-based spirit of capitalism, which was designed to address the artistic critique. Chiapello (2013) suggests that this critique is distinct from any previously faced by capitalism, and demands a specific answer. We suggest that CSR might be viewed as an important response to this critique. Our research focuses on the way the sustainability critique is now raised, acknowledged and (to some extent) addressed in the CSR literature for managers, and whether this integration might lead to a new spirit of capitalism, resulting in the desired changes at the level of corporate activities. In the next section, we present our research methodology.

\section{Method}

To answer our questions, we adopted the research approach applied by Boltanski and Chiapello, who analysed managerial texts aimed at 'informing cadres [of managers] of the latest developments in running firms and managing human beings' (2005: 57). We followed the same line of reasoning, first searching for books on CSR that offered advice to managers, consultants and other individuals who work in, with or for companies. We presented our selection to four scholars, who are all full professors in CSR, established in the UK and North America, and engaged in teaching MBA and executive courses; with their help, we refined our selection. This consultative process aimed to ensure that our selection included only those books for managers that are regarded by expert colleagues as important CSR references for this audience. This method of selection is consistent with the approach adopted by other scholars. For example, Barley et al. (1988) asked their colleagues who specialized in the area they were considering (organizational culture) to identify practitioner literature. This method has its limitations, yet we believe it is an improvement on Boltanski and Chiapello's (2005) initial work, where there was no clear method to select books, a point that generated several critiques when their work was initially published (see Leca and Naccache, 2008 for a review of these debates). We then excluded disciplinary and technical texts, presenting corporate codes of conduct and general advice on CSR for managers. This selection has been reworked 
iteratively as we have presented and received comments on this research at three CSR seminars and workshops that included academics and practitioners. At the end of this process, we had obtained a corpus of 20 managerial texts on CSR, which we further revised on the basis of the suggestions offered by the reviewers of this paper. This eventually led us to select a corpus of 22 managerial books (detailed in Appendix 1).

We read each of these books line by line, and analysed them along the five dimensions drawn from Boltanski and Chiapello’s (2005) initial work:

1. Are critiques of capitalism mentioned?

2. If so, how are they presented and addressed?

3. What sort of excitement is proposed to support the directions suggested (if any)?

4. What type of security is proposed to support the directions suggested (if any)?

5. What notion of fairness is advocated to support the directions suggested (if any)?

Each book was read by two of the co-authors. We constructed a spreadsheet, with the books in rows and the five dimensions in columns, and added a sixth column for comments, questions and queries. We populated the columns with notes, quotations and summaries related to the five dimensions. For each question, we analysed the text to review how a particular dimension was (or was not) addressed by the book, recorded the relevant information and added our comments in the sixth column. When in disagreement, the third co-author read the book to arrive at a shared understanding of the text. The process led us to obtain 132 records. We discussed each record and linked it with other records to interpret similarities, differences and variations. We used this material to structure our argument and presented it to interested academics for comments; these were then used to revisit the main 
arguments and associated evidence. Our approach is an interpretive account of what the authors wrote. This is consistent with Boltanski and Chiapello's method. While we do not claim to represent the 'reality' of what the authors wrote, we have tried to avoid a subjective account by collective reading and interpretation, and by providing some quotations from the books so that readers can appreciate whether they agree with our interpretation.

The present approach has clear limitations. Exploring the managerial literature is difficult because it is always challenging to construct a 'representative corpus'. Furthermore, selecting managerial books is an uncertain process as even though one can ensure that selected books are well known in the specific domain, it is impossible to establish whether managers actually read those books. Even if they do read them, it would be difficult to assess whether they then introduce the recommended changes to their organizations. Our study does not claim immunity from these limitations. However, it follows a tradition of using managerial literature to observe and analyse the transformation in capitalism (e.g. Weber, [1930] 1992; Sombart, [1913] 1967). Also, our analysis is context-specific, since our selection is limited to books written in English, mostly by authors based in English-speaking countries. A different selection, from authors based in different cultural areas, may provide different results. In the next section, we present our research findings.

\section{CSR as a potential new spirit of capitalism}

In this part, we present the analysis of the corpus of 22 managerial CSR books listed in Appendix 1. Our analysis is structured using the five dimensions mentioned in the previous section, so this section is organized in the same way. It begins with the critiques of capitalism.

\section{Critiquing capitalism}

Boltanski and Chiapello (2005) suggest that those criticizing capitalism identify the contradictions and problems of the current form of capitalism that can be used as evidence by 
promoters of capitalism to induce change. Promoters might point at these contradictions and problems, or draw from them to justify their recommendations. The first step, therefore, in line with the approach of Boltanski and Chiapello, is to consider the critiques of capitalism. The texts in our corpus present two distinct but interrelated critiques: the unsustainable nature of corporate capitalism; and its moral emptiness as a system where corporations operate only for their own and their shareholders' gain.

The selected texts hold corporations responsible for exhausting limited and fragile natural resources, and for increasing pollution (e.g. Anderson, 1998; Elkington, 1997; Grayson and Hodges, 2001; Senge et al., 2008), and also address issues related to human rights and child labour in which corporations are involved (Elkington, 1997; Grayson and Hodges, 2001). Jackson and Nelson (2004) argue that corporate capitalism is 'under siege' and faces a 'crisis of sustainability'. The texts show how the organization of corporations prevents them from contributing to social and natural environments, and how they use social and environmental resources inappropriately to maximize profits. Anita Roddick, in her book Business as Unusual (2001: 8), lucidly comments on the unsustainability of corporate capitalism by labelling it 'the new nomadic capital' that 'never sets down roots, never builds communities'. She continues: 'It leaves behind toxic wastes, embittered workers and indigenous communities driven out of existence'.

Our corpus suggests that the unsustainability of corporate capitalism is a consequence of the pressure of financial performance, which is the sole concern of corporate executives (e.g. de Woot, 2005; Roddick, 2001). Executives tend to ignore other forms of value generation, as well as other forms of value (Elkington, 1997). The focus on financial performance leads to a short-term outlook, because of the demands of financial and stock markets (de Woot, 2005; Senge et al., 2008), which require corporations to provide immediate returns to their shareholders (e.g. Hawkins, 2006). This induces aggressive accounting methods and 
unrealistic valuation models. These models cause a massive build-up of debt and acquisitions, destroying the value of shares and demonstrating the incompetence of management (Hancock, 2004).

The second critique related to the moral emptiness of corporate capitalism. All critiques of capitalism include some comment on capitalism's moral emptiness; the sustainability critique is no exception. Some of the books we analysed endorse this moral critique. These texts set the tone of this critique by labelling corporate capitalism as 'uncivil' (Davis et al., 2006), 'lacking a sense of spirituality’ (Roddick, 2001) or 'untrustworthy' (de Woot, 2005; Jackson and Nelson, 2004). The authors argue that corporate capitalism suffers from a 'loss of meaning' (de Woot, 2005), as corporations have disregarded their moral obligations (Roddick, 2001). More specific to the sustainability critique, the denounced moral emptiness relates to the selfishness of companies working only to increase their profits and the satisfaction of their shareholders while ignoring the effects of their activities on the larger society and natural environment (Anderson, 1998, 2009). It is suggested that, to regain moral meaning, corporations need to abandon such selfishness and shift from 'consumption ideology' to 'builder's ideology' (Jonker and de Witte, 2006), and to replace the 'invisible hand', which fails to guarantee the common good (de Woot, 2005), with a 'helping hand' (Elkington, 1997). The texts substantiate and validate their critiques by providing empirical data or by referring to critical thinkers. Such critical thinkers include, for instance, Michael Hardt and Toni Negri (McIntosh, 2003), and Robert Kuttner (Elkington, 1997; Roddick, 2001). However, some texts in our corpus consider these critiques as too radical and biased. Griffin (2008: 157) argues, for instance:

[The] CSR agenda is not a debate about how companies can use their power, their expertise and their money to ensure capitalism and globalization benefit many not the 
few. It is a debate about how the world works, with a vociferous lobby saying that whatever companies do is for the detriment of the world.

Hilton and Gibbons (2004: 51) share this view, and declare that radical critiques of corporate capitalism are 'heresy', representing a simplistic discourse based on a selective use of statistical data. They state:

This is a defining battle of the twenty-first century, not between people and corporations, as George Monbiot argues: corporations are comprised of people they're on the same side. The battle will be between those who see nothing but a negative social role of business, and those who want to promote the positive.

Even though these authors challenge the radical elements of the critiques of corporate capitalism, they nonetheless stress the need to engage with them, and consider CSR the best way for corporations to respond to the critiques. How corporations might do so is the main topic in the next section.

\section{Addressing the critiques}

Boltanski and Chiapello (2005) point out how critical and managerial literatures diverge on the issue of how to use the critiques of capitalism. While critical texts demand radical changes to promote alternatives to capitalism, or to reduce the role of the market economy, managerial texts take a reformist stand. How CMS and managerial literature account for sustainability is typical of this. Critical authors see in sustainability a challenge that capitalism cannot address; they then call for profound changes (e.g. Alperovitz, 2011; Klein, 2014). On the contrary, the managerial books that we analysed use critiques as a way to legitimize their call for reform without radically questioning capitalism. We suspect that the authors might have selected only those critiques of capitalism that could be addressed within the framework of corporate capitalism. Our corpus consider CSR as an appropriate reformist response to two distinct critiques: the crisis of sustainability, and that of moral emptiness. The 
authors of the texts have used diverse rhetorical strategies to present their reformist advice. Some authors see the new critiques of capitalism as a problem, threatening its future (Hilton and Gibbons, 2004; Jackson and Nelson, 2004), while others present the critiques as a context that demands changes in the way corporations operate (e.g. Elkington, 1997; Jonker and de Witte, 2006; Roddick, 2001). While most of the texts engage with critiques in one way or another, six books do not discuss them, posing capitalism as a solution but not a problem, and instead focusing on CSR itself (e.g. Handy and Handy, 2007; Hopkins, 2007; Kotler and Lee, 2005). In this sense, all the texts in our corpus begin by spelling out a perspective that gives meaning to a CSR-based model. In so doing, they propose three options that could help firms respond to the critiques: remodelling corporate activities based on addressing new stakeholders' values and demands; reorganizing corporate governance; and widening the socio-economic functions and goals of corporate activities.

A first way to address the critiques is to remodel the corporate activities from the perspective of stakeholders' values and demands. The authors argue that corporations have been neglecting certain strategic dimensions that are appealing to important stakeholders and that they now should integrate them (e.g. de Woot, 2005; Zadek, 2007). Kotler and Lee (2005) argue that consumers' new demands reflect a more general societal change and should be integrated into corporate strategies. It is now necessary to go beyond the practical issues of functional product performance and address consumer demand for brands to 'behave' in a way that complies with their own values. With this approach to critiques, the authors propose the value-based remodelling of corporate strategic orientation, and claim that this would solve the problems associated with the corporate organization of capitalism. For example, Davis et al. (2006) see in the increasing number of people holding shares in companies an opportunity for these shareholders to demand that corporations address the environmental and social issues associated with their operations. 
The second approach insists on the need to reorganize corporate governance by involving stakeholders. Corporations need to engage with their stakeholders to ensure sustainable growth (Zadek, 2007), to secure a good reputation and a licence to operate (Griffin, 2008), and to address the need for accountability towards stakeholders (e.g. Davis et al., 2006). It is argued that companies must not limit the way they manage stakeholders to the avoidance of conflict, but must take a stronger line and proactively find ways to work with them (Griffin, 2008). This, some authors argue, would address the weakness of the current management model, which produces a gap between the interests of business and those of society. A dialogue allows companies to forge new alliances (Jackson and Nelson, 2004) and to contribute to the common good (de Woot, 2005); they will then be doing well by doing good (Jonker and de Witte, 2006).

The third approach proposes that companies should enlarge their socio-economic goals. managers should address big issues, such as the alleviation of poverty (Prahalad, 2005) or international development (Hopkins, 2007), rather than spending time and effort trying to justify themselves against the critiques (e.g. Grayson and Hodges, 2001). Authors offer different goals, for example sustainability (Elkington, 1997), as ways to redirect corporate strategy. They introduce and elaborate concepts and practical tools to move beyond stakeholder management. These ideas include the triple bottom-line approach developed by Elkington (1997), and the corporate citizenship policy advocated by McIntosh et al. (2003). These approaches, according to these authors, imply fundamental changes in the way corporations are currently organized and managed.

The level and scope of change proposed appear to vary significantly in relation to the way the different texts approach the new critiques of capitalism. All 22 texts in our corpus provide managers with practical tools and examples, and not just concepts, to address the critiques and engage with the new challenges. Although all the texts in our analysis consider CSR as 
an appropriate reformist response to 'the crisis of capitalism', at least seven texts also see CSR as a new business opportunity. They tell success stories of doing business in line with CSR (e.g. Handy and Handy, 2007). They then declare that corporations can make a fortune by addressing issues relating to international development (Hopkins, 2007), poverty alleviation (e.g. Prahalad, 2005) or climate change (Senge et al., 2008). These texts call for a new form of capitalism (e.g. Davis et al., 2006), but do not consider this as a radical departure from the previous model. Instead, this new capitalism is an extension of current business principles to new issues and markets (e.g. Kotler and Lee, 2005; Prahalad, 2005). For example, Kotler and Lee (2005: 10, our italics) argue:

It appears that such participation looks good to potential consumers, investors, financial analysts, business colleagues, in annual reports and in the news, and maybe even in Congress and the courtroom. It is reported that it feels good to employees, current customers, stockholders, and board members. There is growing evidence that it does good to the brand and the bottom line as well as the community.

Although these texts present CSR as a new business opportunity, they also regard it as an important way to respond to the 'moral emptiness' of corporate capitalism (see, for example, Kotler and Lee, 2005). CSR is viewed as a way of assisting consumers to accomplish selfrealization, which has become, according to these texts, an important concern in consumer behaviour. In short, CSR is presented as both a necessity and an opportunity for corporations.

The texts critically analyse corporate capitalism. Authors clearly doubt that capitalists and wage-earners can gain excitement from getting involved with capitalism, and they use this point to introduce alternatives forms of capitalism in which CSR is central. Since the adoption of a new model depends on motivating managers, managerial texts need to show how it will benefit them. In the next section, we consider the forms of excitement inherent in 
a new CSR-based model, i.e. identifying and examining the potential sources of satisfaction for people involved in performing and managing businesses along the lines of that model.

\section{Offering excitement}

Boltanski and Chiapello (2005) argue that capitalism is not exciting in itself, as it involves a restless drive to accumulate capital as well as a 'willing' subordination by wage-earners, who have to relinquish both the fruit of their labour and the wealth it generates. In such an order, the 'spirit' needs to provide protagonists of capitalism with a source of excitement. The texts we analysed present two distinct but interrelated sources of excitement.

The first focuses on individuals involved in capitalism, and presents them with an opportunity to align their moral values with their economic interests. The texts declare that wage-earners suffer from dissonance between their moral values and their economic interests (Roddick, 2001), and this tension is central to how capitalism is currently organized. CSR can reduce this dissonance, as it reconciles profits with principles (Hawkins, 2006; Jackson and Nelson, 2004). The texts proclaim that CSR is an opportunity to re-energize the business around a new and exciting project (Hancock, 2004). CSR offers a richer, more diverse work experience, where several forms of value - besides financial profits - are considered important. The values-based management made possible with CSR is a way to reinforce the sense of community at work, and to consolidate organizational identity and culture (Jonker and de Witte, 2006; Roddick, 2001). The second source of excitement focuses on corporations, and tells the individuals who run them that a CSR-based model will accomplish both social and reputational goals by improving the relations between corporations and the wider community in which they operate. This is possible, according to authors, because there is allegedly an alignment between the social and the economic performance of the firm (Jonker and de Witte, 2006). This echoes the 'business case' approach to CSR whereby 
improved corporate social performance is believed to contribute to improved corporate financial performance (Anderson, 2009; Jackson and Nelson, 2006; Prahalad, 2005).

Although the removal of moral dissonance is presented as a main source of excitement, some books also point to the benefits of using CSR to attract the best brains (Jackson and Nelson, 2004; Kotler and Lee, 2005), and to increase productivity and quality (Anderson, 2009; Hawkins, 2006). Crucially the texts repeatedly argue that CSR will improve relations between corporations and the wider community in which they operate. CSR offers means by which businesses can acquire social capital, which in turn may generate intangible corporate assets such as mutual confidence, trust, and actions that would not otherwise be possible (Jonker and de Witte, 2006). CSR is a way to restore public trust in the corporate world (Hancock, 2004). It follows that CSR enhances the corporation's reputation (Jackson and Nelson, 2004) and confirms its licence to operate (Hancock, 2004). Moreover, wage-earners will be excited by working in a company with a high CSR profile, and will be proud of it (Hawkins, 2006).

What is remarkable here is that CSR-related sources of excitement appear to be in sharp contrast with the sources of excitement in the previous spirit of capitalism identified by Boltanski and Chiapello (2005). According to them, a central common characteristic of the sources of excitement provided by successive spirits of capitalism relates to 'freeing' wageearners. For instance, in what they identified as the third spirit of capitalism (see Table 1), flexible organizations and innovation are presented as ways to free individuals from bureaucracy and from the alienating effect of much routine (see Table 1). Texts promoting CSR offer a sharp contrast with this dynamic of increasing individual freedom. Rather than emphasizing individual freedom, the texts stress one's duties to the collective, and spell out the benefits (not only economic but also moral and social) that corporations and individuals could gain from CSR. The current spirit of capitalism focuses on the individual and can be 
criticized for favouring anomie by disregarding generally accepted norms and values (Boltanski and Chiapello, 2005). Part of the excitement offered by CSR as a potential new spirit is to reduce this anomie by reconnecting business to wider society, as well as by offering the possibility of aligning the moral values of the protagonists of capitalism with their economic interests.

\section{Guaranteeing security}

Boltanski and Chiapello (2005) argue that to gain support for a new spirit of capitalism, its promoters must convince people that working within the proposed version of capitalism will bring them some security. While the third spirit of capitalism demands that wage-earners renounce the idea of a lifetime job in exchange for a more exciting project-based career, it also insists on corporations' duty to ensure the employability of their wage-earners, so they will have a safety net in the form of job prospects outside the company in the event they cannot find a position within the company's own projects. Security is a central part of the argument developed by CSR promoters. However, the approach to security developed here is different from that in previous spirits of capitalism. Three types of security improvements can be found in our corpus: for society as a whole; for corporations; and for individuals and future generations.

The books present CSR as a solution to the threat from the current version of capitalism to the long-term security of society as a whole. This, the texts claim, is a key advantage of CSRdriven models. As we mentioned earlier, one of the main critiques of corporate capitalism considers it unsustainable in demanding more resources than the planet can provide (Senge et al., 2008). Therefore, it is seen as a major threat to the security of future generations. The texts argue that the alternatives they propose and promote deliver sustainable development that is central to providing security to future generations (de Woot, 2005; Hawkins, 2006). CSR is also presented as a way to ensure the long-term security of corporations, as it should 
strengthen ties between corporations and the wider society. Foster and Jonker (in Jonker and de Witte, 2006: 127) declare: 'No corporation can be immune from this societal framework in the long term and its very survival is dependent on the way in which it engages with that framework.'

CSR is presented as a way to secure the legitimacy of companies, which is a matter of survival (Stinchcombe, 1965), as well as of reputation (Jackson and Nelson, 2004). The books also enumerate several other benefits from CSR that are likely to increase companies' economic success and chances of survival, including the development of new markets (Prahalad, 2005), innovation and repositioning (Senge et al., 2008), reduction of risk (Hancock, 2004) and increased capacity to attract bright people willing to work for CSRdriven corporations (e.g. Jackson and Nelson, 2004). Less effort seems to go into explaining how CSR can improve the security of individuals themselves. Grayson and Hodges (2001) state that employers have a duty to improve the employability of wage-earners, and to help them to cope with restructuring and to develop career resilience. They suggest: 'Security of employment can be said to be giving way to security of employability' (Grayson and Hodges, 2001: 112). This approach is quite close to that already identified by Boltanski and Chiapello (2005) as typical of the third spirit of capitalism, which insists on the need to develop employability and career resilience.

It seems that while the long-term security of society and corporations is discussed and argued about at length, limited attention is paid to improving the security of wage-earners, for example by promising lifelong careers. This characteristic of CSR, advocated by the texts we analysed, also features in the discussions relating to fairness, to which we now turn our attention. 


\section{Fairness}

One last but very important dimension of the spirit of capitalism, according to Boltanski and Chiapello (2005), is to give people a sense that, by supporting and working within capitalism, they will be rewarded in a fair way. For example, in the current spirit of capitalism - evident in project-based organizations - fairness is embedded in the evaluation of wage-earners, based on their adaptability, mobility and capacity to fulfil projects. Our analysis of managerial texts suggests a distinction emerging among wage-earners, i.e. between managers and workers. While the authors address the issue of fairness for top managers, for whom they recommend rewards, they give little attention to the workers.

The texts we analysed are targeted at managers rather than workers. They insist on the importance of top leadership and regard managers, in particular senior managers and CEOs, as the main driving force in CSR policies (Davis et al., 2006; Elkington, 2001; Hawkins, 2006; Jackson and Nelson, 2004; Senge et al., 2008). Some authors recommend direct financial rewards for managers' engagement in CSR. Grayson and Hodges suggest basing managers' bonuses on dimensions such as diversity and human rights (2001: 265). Davis et al. (2006) (a) recommend that managers should be paid to do the right thing; and (b) insist that remuneration should not be connected to share price. In sharp contrast, when considering rewards for workers, the texts tend to perceive the rewards as more symbolic and less financial. CSR is presented as a way of giving staff an opportunity to express their idealism (Roddick, 2001). Hilton and Gibbons (2004) suggest that workers who are willing to engage with CSR will be considered smart and concerned citizens. Davis et al. (2006: 211) also point out that the concept of reward is not limited to money; they suggest that a new policy can lead to a better workplace culture and to non-monetary rewards, such as 'positive working environment, status, the feeling of having made a contribution to something worthwhile'. Other authors emphasize that wage-earners can draw from CSR benefits related to the 
development of skills and employability (Hancock, 2004; Jackson and Nelson, 2004). While Grayson and Hodges suggest including dimensions such as diversity and human rights in the evaluation of managers' bonuses, they say when considering wage-earners: 'For wageearners ... motivation is based on values rather than purely on financial reward' (2001: 76). Being more allusive, Jonker and de Witte (2006: 25) suggest that actions, if institutionalized within the company, will reward employees. In other words, while remuneration is viewed as too narrow a motivation for workers, it is considered a valuable motivation for managers.

One possible explanation for this difference is that some authors emphasize the need for leadership and the need to reward leaders in projects to implement CSR (e.g. Zadek, 2007). They see the implementation of CSR as a major change requiring a top-down process, where leadership from managers is essential (Elkington, 2001). Within this perspective, the lack of tangible rewards for workers may be just an omission, as the texts concentrate on those issues that the authors view as more important. Nevertheless, according to Boltanski and Chiapello (2005), it might become problematic when trying to convince the protagonists of capitalism and to ensure implementation, especially since it creates a divide between managers and workers in the incentives to implement CSR.

\section{Discussion and conclusion}

The analysis presented in the previous sections provides important insights relating to our two questions: does CSR (as advocated in the managerial literature we have analysed) exhibit the characteristics of a new spirit of capitalism, and is that spirit likely to change corporate capitalism and its activities in ways consistent with the standpoint of CMS? Below, we present and discuss the answers to these questions.

Following the analytical logic developed by Boltanski and Chiapello (2005), our analysis suggests that CSR does exhibit the core characteristics of a spirit of capitalism. The books acknowledge the selected critiques of corporate capitalism and intend to address them; to do 
so, they call for changes in practice, make recommendations regarding how those changes should be introduced, and spell out the benefits that corporations, managers and employees may obtain. They do not promote the maintenance of 'business as usual', but call for reforms and aim to influence the current management of corporations, arguing that a new form of capitalism might be part of the solution, much as the current one is part of the problem. The authors present CSR as a new and exciting way of engaging with corporate capitalism, as it can potentially connect corporations to wider society - as well as offering an opportunity to protagonists of corporate capitalism to align their moral values with their economic interests. CSR, is presented as a step to secure the continuity and growth of corporations, society and future generations and . as a new way of organizing fairness, which makes top management a direct beneficiary of CSR-driven change. This rather supports the position of the authors, who see in CSR a way to induce profound changes in corporate capitalism (see, for example, Edwards, 1999; Lantos, 2001; Margolis and Walsh, 2003).

Yet, two characteristics of the spirit of capitalism, as identified by Boltanski and Chiapello (2005), are underdeveloped (see Table 2). First, when discussing the security that CSR can provide, the texts pay more attention to the security of the company - i.e. its capacity to ensure good relations with external stakeholders, and sustainable growth - than to the security of the individuals within the company, thus overlooking their individual interests and needs. Second, while Boltanski and Chiapello insist on the need to treat fairly all the protagonists of corporate capitalism who support a new spirit of capitalism, the books make a clear distinction between managers and employees. The CSR-based model seems to represent a top-down process in which the support of managers is crucial; bottom-up processes to enact CSR seem to be ignored in the managerial discourse that we have considered. This has led to a rather unusual view of fairness, where managers who lead, develop and enact CSR can expect financial rewards, while workers receive only the symbolic satisfaction of working in 
a company engaged in CSR. This could potentially lead workers to consider CSR as a way to increase managers' financial gains but not their own, and therefore it may create tension between top management and workers on CSR-related issues.

Table 2. CSR as a potential fourth spirit of capitalism in the making.

\begin{tabular}{|c|c|}
\hline & Corporate social responsibility \\
\hline Critiques & $\begin{array}{l}\text { Unsustainability } \\
\text { Moral emptiness }\end{array}$ \\
\hline $\begin{array}{l}\text { Addressing the } \\
\text { critiques }\end{array}$ & $\begin{array}{l}\text { Value-based remodelling of corporate activities } \\
\text { based on stakeholders' new demands (e.g. values, } \\
\text { environmental and social issues) } \\
\text { Reorganizing corporate governance by involving } \\
\text { stakeholders } \\
\text { Widening the socio-economic function and goal of } \\
\text { corporate activities }\end{array}$ \\
\hline \multirow[t]{2}{*}{ Excitement } & $\begin{array}{l}\text { For individuals: to align their moral values with } \\
\text { their economic interests }\end{array}$ \\
\hline & $\begin{array}{l}\text { For companies: to improve relations with the wider } \\
\text { society in which they operate; to attract employees }\end{array}$ \\
\hline Security & $\begin{array}{l}\text { Sustainability, long-term security for society and } \\
\text { corporations. But little attention to improving the } \\
\text { security of wage-earners }\end{array}$ \\
\hline Fairness & $\begin{array}{l}\text { Incentives and financial rewards for managers who } \\
\text { implement CSR but no such incentives for } \\
\text { employees. Regarding those employees, authors } \\
\text { insist on the symbolic rewards and improvement of } \\
\text { the work environment that they can expect }\end{array}$ \\
\hline
\end{tabular}

In italics: the dimensions of spirits of capitalism identified by Boltanski and Chiapello (2005) that are missing in the analysed managerial literature promoting corporate social responsibility

The absence of workers in the proposed CSR-based model is not limited to the managerial corpus; Marens (2010: 744), in his analysis of the academic literature on CSR, reaches the same conclusion and declares that "corporate scholars [in CSR] have shown relatively little interest in either labour unions or general employment policies, with the occasional exception 
of the plight of third world workers, safely removed from having to discuss employment practices within the core itself'.

One could argue that there is no issue here because workers are just stakeholders in the same way as any other group, and should not be treated differently. However, this line of reasoning significantly lessens the importance of workers, who - according to Boltanski and Chiapello's (2005) framework - play a decisive role in enacting a spirit of capitalism. Furthermore, even though CSR is being used to promote labour standards and norms (e.g. Global Reporting Initiative, ISO 26000 etc.), the books we have considered give little attention to localized labour issues - for example, the issue of retirement (relating to security) or of financial incentives to promote CSR (relating to fairness). Overall, this suggests that CSR (which aims to extend the number of stakeholders) is - ceteris paribus - likely to take place at the expense of localized needs and workers' interests. Furthermore, while shareholders, managers and employees might all be introduced as equal stakeholders, the books mention financial benefits for shareholders and managers much more often than they mention those for workers.

This absence of attention to workers is also consistent with data on activities within companies. A Eurosif survey (2010) conducted among the 300 biggest European companies (members of the FTSEurofirst 300 Index) revealed that only $29 \%$ of respondents implemented systems where part of their executives' remuneration depended on environmental, social and governance performance. Interestingly, the study does not look at remuneration plans for workers. Companies also seem to place more emphasis on remunerating their executives than their workers for the implementation of CSR. For example, Danone stresses how its commitment to CSR is realized through the 'Danone way', a method for measuring the CSR performance of the company's different sub-units and 
modulating remuneration accordingly. Yet, the Danone way data apply only to the remuneration of the 1400 top executives of the company (Gond and Igalens, 2012).

While the disregard for workers weakens the realization of CSR, Boltanski and Chiapello (2005) insisted that, in order for a new spirit of capitalism to be successful, it must convince all protagonists of capitalism - i.e. capitalists and wage-earners. Workers seem to be the discounted stakeholder in the proposed CSR-driven change; without their involvement, however, CSR may neither grow into a new spirit of capitalism nor induce changes in corporate practices. Our analysis, therefore, leads us to side with those CMS authors (e.g. Banerjee, 2007; Shamir, 2004) who doubt the potential of CSR to introduce changes to corporate capitalism. While the texts we analysed engage with some of the shortcomings of capitalism, they neither question the existing domination over employees nor pay much attention to their needs and interests. The books discuss social injustice and environmental destructiveness in general, but pay little attention to workers. The latter are considered to be like any other stakeholder, despite their unique and central contribution in enacting a spirit of capitalism - so reducing their importance. In this sense, we suggest that the current managerial literature on CSR which we have considered is unlikely to help realize the CMS project.

Our analysis, therefore, incidentally suggests that CMS authors might need to engage more actively to develop a version of CSR that could convey the CMS project. This calls for an engagement that would not only produce academic literature on CSR but also actively contribute to popular and managerial literature, and propose tools such as organizational and material 'engines' (Cabantous et al., forthcoming; Leca et al., 2014) to facilitate the realization of a yet-to-be-elaborated critical CSR. We suggest that putting workers at the centre of this critical CSR project and facilitating bottom-up processes might be a good starting point. It can certainly be argued that our study is limited to managerial texts on CSR 
and that academic research on CSR might better convey the CMS perspective. We would nonetheless argue that managerial texts are more likely to influence managerial practices, while it is uncertain that academic literature does so (Barley et al., 1988).

This study contributes to research on the transformation of the spirits of capitalism, and the cycles of change brought about by its critiques, in three ways. First, in line with Chiapello's recent works $(2009,2013)$, it points to the existence of new critiques unaddressed by the current spirit of capitalism (as described by Boltanski and Chiapello, 2005). Those critiques relate to the sustainability of the capitalist model that emerged in the 1960s and 1970s, and represent radical questioning of capitalism (e.g. Carson, 1962; Kovel, 2007). Our analysis extends Chiapello's works by showing how part of this initially radical critique is integrated into a new spirit of capitalism around the notion of CSR. The latter is presented in the books we analysed as a way to integrate part of the sustainability critique while maintaining capitalism through changing some of the corporations' practices. As a consequence, our study suggests that the sustainability critique is unlikely to remain a radical critique, as it is becoming integrated into capitalism through CSR.

Second, our analysis suggests a process of a potential new spirit of capitalism that is still developing. While previous research by Boltanski and Chiapello (2005) examined a wellestablished spirit of capitalism, this research shows that such spirits are not fully fledged from the start and do not immediately exhibit all the characteristics of clearly defined spirits of capitalism. CSR is still developing, and the arguments to convince protagonists to join this new spirit are still less complete than those developed by previous spirits. This is not surprising if one considers that most of the books we analysed were written during the 2000s, the oldest being the seminal Cannibals with Forks by John Elkington, which even then only dates from 1997. As pointed out above, what is currently missing is a specific sense of fairness and security, as well as the need to devote more attention to the substantive 
incentives required to persuade wage-earners (as protagonists) to join and enact this new spirit of capitalism. It also suggests that, depending on the outcome of efforts to integrate wage-earners further as protagonists, CSR may or may not become a new spirit of capitalism. Potential new spirits, such as CSR, emerge to address critiques, but the extent to which they might actually become dominant over a specific period depends on the capacity of their promoters to satisfy the protagonists of capitalism.

A third contribution to research on the spirits of capitalism results from comparing CSR as a potential new spirit of capitalism with the previous spirits of capitalism. A striking characteristic of CSR that emerges is that it holds no promise of further freedom for individual protagonists, in contrast to all the previous spirits. Instead, CSR insists on the need to reconnect corporations with their members and to re-embed them within wider society, and also on the moral and social benefits that individuals can derive once these organizations are re-embedded. In this approach, individual freedom is less of an issue. One reason for this might be that individuals, after decades of increasing 'freedom' that favoured anomie, are now willing to reduce this anomie. Instead of more freedom, individuals would then demand greater consistency between how they are supposed to behave within society and how they are supposed to behave at work - and, more generally, a better alignment between the interests of business and those of society. If this argument proves appealing, this could constitute a major shift in capitalism, as individuals would ask less for individual freedom and demand more social inclusion.

There are, as we have stressed previously, limitations to this study, the main one being its focus on a limited selection of managerial books, the popularity and impact of which can be challenged. Nevertheless, we believe that examining managerial literature is essential, as it is likely to be more impactful on managerial practices and can prove significant in better 
analysing and comprehending the potential changes in corporate capitalism and in associated practices.

This study opens up important avenues for research on both the impact of CSR and transformation of the spirit of capitalism. The study invites researchers to pay greater attention to managerial literature in researching CSR. Following Boltanski and Chiapello (2005), we suggest that managerial literature is likely to play a major part in the realization of CSR, and the related change in capitalism. Closer attention to it might enable researchers to trace the origins and practices of CSR policies. Our research also suggests that the books examined offer an incomplete view of CSR-driven change. The literature on CSR is likely to develop further, and it might be useful to observe and examine this from the perspective of the spirit of capitalism. Existing works have reviewed the long-term dynamics of CSR, and related ideas, and have adopted a historical perspective (e.g. Carroll, 2008; Van Marrewikj, 2003). This study calls for a more specific analysis of the development of CSR books for managers, in particular since the beginning of the 2000s: are they different from previous books, and in what ways? Pursuing the current analysis during the coming years would show whether authors discuss further the dimensions that seem to be partially ignored by the books so far reviewed, and whether CSR finally becomes a fully developed new spirit of capitalism.

Regarding the framework of the spirit of capitalism, our research suggests that the current unsettled view of CSR as a new spirit of capitalism opens up the possibility of reconsidering the process of transforming the spirits of capitalism. While the existing research in this area has considered already-established spirits of capitalism, analysing the development of a potential new spirit may provide new insights into how diverse critiques of capitalism interact with each other, and how some do not achieve the desired outcome while others do. Further research on this topic could benefit from moving away from outcome-driven research, where researchers already know the final stage (i.e. that the spirit of capitalism they were studying 
finally became dominant), to event-driven research, where they can document the process as it unfolds and eventually record the failures and 'dead ends' of the process, as well as the successes. Regarding this, for example, the Occupy movement offers an interesting exemplar. Boltanski (2011) recently suggests that certain critiques might constitute a meta-critique that would not be integrated by capitalism and that would not co-exist with it. Such a critique challenges the whole system rather than some specific part of it and - because it is based on denouncing the differences between 'reality' (as socially constructed through the cognitive frames offered by the current ideology - here, the spirit of capitalism) and the 'world' of facts (including those facts that do not fit in the constructed reality). Such critiques voice concerns regarding the current justification of capitalism, and question the established domination and supporting institutions within the capitalist system. Such a critique would question the underlying mechanisms by which some dominate others within capitalism, making its integration extremely difficult because domination and inequality among protagonists are the essence of capitalism.

As we have mentioned earlier, our study suggests that the sustainability critique is not such a critique and that it is on the verge of being integrated by capitalism through CSR. Such a meta-critique might better be found in the current Occupy movement. While it is difficult to find a consistent discourse in this movement, precisely because of its highly decentralized form and rejection of leadership, there is an emerging corpus of books accounting for this critique (e.g. Berardi, 2012; Campagna and Campiglio, 2012). Based on this, we suggest that Occupy has two characteristics that are likely to make its critique difficult to integrate. First, beyond the immediate demands for more and better jobs and for better income repartition, the Occupy movement advocates a radical view of democracy demanding power to all people. Such an egalitarian demand seems extremely difficult for capitalism to integrate, as hierarchy and distinction between shareholders and wage-earners are essential features of capitalism. 
Democratic forms of organization seem to be more consistent with alternative organizational forms such as cooperatives (Cheney, Santa Cruz, Peredo and Nazareno, 2014). A second characteristic that might make the integration even more difficult is that Occupy gathered members who had been playing 'according to the rules' (Cordero-Guzman, 2011) and who eventually found out by themselves that the world was different from the 'reality' advocated by the capitalistic ideology. This disillusionment might render it more difficult to convince them anew to contribute faithfully to capitalism. While it is certainly too early to evaluate how this new critique will evolve - and whether and how it will resist integration - it will certainly be an interesting situation to study.

To conclude, in this paper, we drew on Boltanski and Chiapello's (2005) work on the transformation of the spirit of capitalism to contribute to the discussion on the potential of CSR as a source of change in corporate capitalism, and its likely contribution to encouraging the form of management envisioned by CMS. We analysed a corpus of 22 managerial books on CSR, and presented our findings and conclusions. We suggested that CSR, as described in the corpus, exhibited the core characteristics that together exemplify the 'spirit of capitalism', but inadequately addressed the two key characteristics of the spirit of capitalism - security and fairness - by disregarding the individual security of, and tangible rewards for, workers who play decisive roles in transforming the spirit. The failure to consider workers, we argue, could weaken the potential of CSR to grow into a new spirit of capitalism; in this sense, it seems unlikely that CSR will encourage the form of management envisioned by CMS, where the issues of social justice or injustice are central. Our study casts doubt on whether the managerial literature on CSR is currently capable of developing a sufficiently persuasive discourse to bring about the change it advocates.

\section{REFERENCES}


Adler P, Forbes L and Willmott H (2007) Critical management studies. Academy of Management Annals 1(1): 119-179.

Alperovitz G. (2011), America Beyond Capitalism. Washington D.C.: Democracy Collaborative Press and Dollars \& Sense.

Bakan J (2005), The Corporation: The Pathological Pursuit of Profit and Power, Free Press. Banerjee SB (2007), The Good, the Bad and the Ugly. Edgar Elgar Publishing Limited, UK. Barley SR, Meyer GW and Gash DC (1988), Cultures of Culture: Academics, Practitioners and the Pragmatics of Normative Control. Administrative Science Quarterly. 33: 24-60 Berardi F (2012), The Uprising: On Poetry and Finance. MIT Press.

Berland, N and Chiapello E (2009), Criticisms of capitalism, budgeting and the double enrolment: Budgetary control rhetoric and social reform in France in the 1930s and 1950s, Accounting, Organisations and Society 34(1), 28-57.

Boltanski, L (2011), On Critique: A Sociology of Emancipation, Polity Press, Cambridge.

Boltanski, L and E Chiapello. 2002, 'The New Spirit of Capitalism, 'Paper presented in the Conference of Europeanists, March, 14-16, Chicago. Available online:

http://www.darkmatterarchives.net/wp-content/uploads/2011/11/boltanskiSPIRITofCapitalism.pdf

Boltanski, Luc and Eve Chiapello. 2005, The New Spirit of Capitalism, Trans. G. Elliott, (Verso London, UK)

Cabantous, L, Gond, J. P. and Harding, N. and Learmonth, M. (Forthcoming) Reconsidering critical performativity. Human Relations

Campagna $\mathrm{F}$ and Campiglio $\mathrm{E}$ (Eds) (2012) What we are fighting for : a radical collective manifesto. London: Pluto Press.Carroll, AB (2008) A history of corporate social responsibility. Concepts and practices. In: Crane, A. McWilliams, A., Matten, D., 
Moon J. and D. Siegel (eds.), The Oxford Handbook of Corporate Social responsibility, (Oxford University Press, New York), 19-46

Carson, R (1962) Silent Spring. London: Penguin Books

Cheney G, Santa Cruz I, Peredo AM and Nazareno E. (2014) Worker cooperatives as an organizational alternative: Challenges, achievements and promise in business governance and ownership. Organization 21: 591-603.

Chiapello, E (2003) Reconciling the Two Principal Meanings of the Notion of Ideology The Example of the Concept of the 'Spirit of Capitalism' European Journal of Social Theory 6(2), 155-171.

Chiapello, E (2009) 'Le Capitalisme et ses critiques', Presentation at the 6th RIODD Conference, June 25-27, Lille.

Chiapello, E (2013) Capitalism and its criticisms. In du Gay P and Morgan G (eds.) New spirits of capitalisms Oxford University Press, 60-82.

Christensen LT, Moring M and Thyssen O (2013) CSR as aspirational talk. Organization 20(3): 372-393Christiansen CO (2010) Lost in translation: Bringing Hirschman's concept of voice back into the spirit of capitalism. Management \& Organizational History 5(1) 19-35.

Cordero-Guzman, HR (2011). Main Stream Support for a Mainstream Movement: The 99\% Movement Comes From and Looks Like the 99. Retrieved from: occupywallst.org/media/pdf/OWS-profile1-10-18-11-sent-v2-HRCG.pdf

Cremin, C (2010) Never Employable Enough: The (Im)possibility of Satisfying the Boss's Desire. Organization 17(2): 131-149.

Critchley, S (2007) Infinitely Demanding: Ethics of Commitment, Politics of Resistance. London: Verso. 
Debord, G (1977) The Society of Spectacle. Black \& Red.

du Gay P and Morgan G (eds.) (2013) New spirits of capitalisms Oxford University Press

Edwards M (1999). Future Positive: International Co-operation in the $21^{\text {st }}$ Century. London: Earthscan.

Eurosif (2010) Remuneration. Theme Report. Accessible online:

http://www.eurosif.org/research/theme-reports/remuneration

Fleming P, Roberts, J and Garsten C (2013) In search of corporate social responsibility: Introduction to special issue. Organization 20(3): 337-348.

Gond J.P. and Igalens J (2012) Manager la responsabilité sociale de l'entreprise. Paris : Pearson

Hirschman, AO (1977) The Passions and the Interests. Princeton: Princeton University Press. Jameson F (1991), Postmodernism, or the Cultural Logic of Late Capitalism. (Verso) Klein N (2000) No Logo. Flamingo: London.

Klein N (2014) This changes everything. New York: Simon and Schuster, 2014

Kovel J (2007) The Enemy of Nature: The End of Capitalism or the End of the World? 2nd ed. London and New York: Zed Books.

Lantos GP (2001) The boundaries of strategic corporate social responsibility. Journal of Consumer Marketing, 18(7), 595-632.

Leca B and Naccache P (2008) Book Review: 'Le Nouvel Esprit du Capitalisme': Some Reflections from France: The New Spirit of Capitalism by Luc Boltanski and Eve Chiapello. Organization. 15(4), 614-620. 
Leca B, Gond JP and Barin-Cruz L. (2014) Building critical performativity engines for deprived communities. The construction of popular cooperative incubators in Brazil. Organization 21: 683-712.

Marens R. (2010) Destroying the village to save it: corporate social responsibility, labour relations, and the rise and fall of American hegemony. Organization, 17/6: 743-766.

Margolis JD and Walsh JP (2003) Misery Loves Companies: Rethinking Social Initiatives by Business Administrative Science Quarterly 48, 268-305.

Meadows D, H., Dennis L. Meadows, Jorgen Randers and William W. Behrens III (1972) Limits of Growth. Universe Books: New York.

Parker M (2008) The Seventh City. Organization 15(4): 610-614.

Pocock, J.G.A. (1972) Virtue and Commerce in the Eighteenth Century Journal of Interdisciplinary History III: 119-134.

Pocock, J.G.A. (1985) Virtue, commerce, and history: Essays on political thought and history, chiefly in the eighteenth century. Cambridge, UK: Cambridge University Press.

Purser, R.E., Park, C. and Montuori, A. (1995) Limits to anthropocentrism: toward an ecocentric organization paradigm. Academy of Management Review, 20 (4): 1053-1089

Shamir, R (2004). The de-radicalization of corporate social responsibility. Critical Sociology, $30(3): 669-689$.

Sombart W [1913] (1967) The Quintessence of Capitalism, A study of the History and Psychology of the Modern Business Man New York : Howard Fetig

Spicer A, Alvesson M and Kärreman D (2009) Critical performativity: The unfinished business of critical management studies. Human Relations 62(4): 537-560. 
Stiglitz, J (2006) Making Globalisation Work: Penguin Books

Stinchcombe, AL (1965) 'Social structure and organizations', In J.G. March (ed.), Handbook of Organizations, (Rand McNally, Chicago, IL), 163-78.

Van Marrewikj M (2003) Concepts and Definitions of CSR and Corporate Sustainability Between Agency and Communion. Journal of Business Ethics 44(2-3), 95-105.

Weber M [1930] (1992) The Protestant Ethic and the Spirit of Capitalism. London: Routledge.

Wickert C and Schaefer SM (2014) Towards a progressive understanding of performativity in critical management studies. Human Relations 68(1), 107-130. 


\section{Appendix 1}

\section{List of the reviewed books (by alphabetical order of authors' names)}

1. Anderson RC (1998) Mid-Course Correction: Toward a Sustainable Enterprise: The Interface Model. White River Junction, Vermont: Chelsea Green Publishing.

2. Anderson RC (2009) Confessions of a Radical Industrialist. New York: St Martin's Press.

3. Davis S, Lukomnik J and Pitt-Watson D (2006) The New Capitalists. How citizen investors are reshaping the corporate agenda. Boston, MA: Harvard Business School Press.

4. de Woot P (2005) Should Prometheus be bound?: an essay on corporate social responsibility. Basingstoke: Palgrave Macmillan.

5. Elkington JB (1997) Cannibals with Forks. Oxford: Capstone Publishing.

6. Elkington JB (2001) The chrysalis economy: how citizen CEOs and corporations can fuse values and value creation. Oxford: Capstone Publishing.

7. Grayson D and Hodges A (2001) Everybody's Business. London: Dorling Kindersley Limited.

8. Griffin A. (2008) New strategies for reputation management: gaining control of issues, crises \& corporate social responsibility. London \& Sterling, VA: Kogan Page.

9. Hancock, J (2004) Investing in Corporate Social Responsibility: A Guide to Best Practice, Business Planning \& the UK's Leading Companies. London \& Sterling, VA: Kogan Page.

10. Handy C and Handy E (2007) New Philanthropists. London: William Heinemann.

11. Hawkins DE (2006) Corporate Social Responsibility: Balancing Tomorrow's Sustainability and Today's Profitability Basingstoke: Palgrave Macmillan.

12. Hilton S and Gibbons G (2004) Good Business - Making money by making the world better. New York: Thomson Texere.

13. Hopkins M (2007) Corporate social responsibility and international development: is business the solution? London: Earthscan UK.

14. Jackson, I and Nelson J (2004) Profits with Principles: Seven Strategies for Delivering Value with Values. New York: Doubleday.

15. Jonker J and de Witte M (eds.) (2006) Challenge of organizing and implementing corporate social responsibility. Basingstoke: Palgrave Macmillan. 
16. Kotler P and Lee N (2005) Corporate social responsibility: doing the most good for your company and your cause. Hoben, NJ: John Wiley \& Sons.

17. McIntosh M (2003) Raising a Ladder to the Moon: Corporate Citizenship in the $21^{\text {st }}$ Century. London \& New York: Palgrave.

18. McIntosh M, Thomas R, Leipziger D and Coleman G (2003) Living Corporate Citizenship: Strategic Routes to Socially Responsible Business. London: Financial Times \& Pearson.

19. Prahalad CK (2005) The Fortune at the Bottom Of the Pyramid. Wharton School Publishing.

20. Roddick A (2001) Business as unusual: The triumph of Anita Roddick. Glasgow: Thorsons/HarperCollins.

21. Senge P, Smith B, Kruschwitz N, Laur J and Schley S (2008) The Necessary Revolution. How Individuals and Organizations Are Working Together to Create a Sustainable World. New York: Doubleday.

22. Zadek S (2007) Civil Corporation. London: Earthscan UK 